Review

\title{
Novel Techniques for Microbiological Safety in Meat and Fish Industries
}

\author{
Maksim Rebezov ${ }^{1}$, Muhammad Farhan Jahangir Chughtai ${ }^{2}{ }^{\mathbb{D}}$, Tariq Mehmood ${ }^{2}$, Adnan Khaliq ${ }^{2}$, \\ Saira Tanweer ${ }^{3}$ D , Anastasia Semenova ${ }^{1}$ (D), Mars Khayrullin ${ }^{1,4}$, Andrey Dydykin ${ }^{1}$, Stepan Burlankov ${ }^{5}$, \\ Muthu Thiruvengadam ${ }^{6}(\mathbb{D})$, Mohammad Ali Shariati ${ }^{1,4, * \mathbb{D}}$ and José M. Lorenzo ${ }^{7,8, *(D)}$
}

\section{check for}

updates

Citation: Rebezov, M.; Farhan Jahangir Chughtai, M.; Mehmood, T.; Khaliq, A.; Tanweer, S.; Semenova, A.; Khayrullin, M.; Dydykin, A.; Burlankov, S.; Thiruvengadam, M.; et al. Novel Techniques for Microbiological Safety in Meat and Fish Industries. Appl. Sci. 2022, 12, 319. https://doi.org/10.3390/ app12010319

Academic Editor: Antonio Valero

Received: 22 November 2021

Accepted: 23 December 2021

Published: 29 December 2021

Publisher's Note: MDPI stays neutral with regard to jurisdictional claims in published maps and institutional affiliations.

Copyright: (c) 2021 by the authors Licensee MDPI, Basel, Switzerland. This article is an open access article distributed under the terms and conditions of the Creative Commons Attribution (CC BY) license (https:// creativecommons.org/licenses/by/ $4.0 /)$.
1 Research Department, V. M. Gorbatov Federal Research Center for Food Systems, 26 Talalikhina Str., 109316 Moscow, Russia; rebezov@ya.ru (M.R.); a.semenova@fncps.ru (A.S.); khairullin-mars@ya.ru (M.K.); a.didikin@fncps.ru (A.D.)

2 Department of Food Science and Technology, Faculty of Engineering and Technology, Khwaja Fareed University of Engineering and Information Technology, Rahim Yar Khan 64200, Pakistan; Farhan.chughtai@kfueit.edu.pk (M.F.J.C.); tariq.mehmood@kfueit.edu.pk (T.M.); adnan.khaliq@kfueit.edu.pk (A.K.)

3 University College of Agriculture and Environmental Sciences, Islamia University, Bahawalpur 63100, Pakistan; sairatanweer1116@gmail.com

4 Research Department, K. G. Razumovsky Moscow State University of Technologies and Management (The First Cossack University), 73 Zemlyanoy Val, 109004 Moscow, Russia

5 Research Department, Plekhanov Russian University of Economics, 36 Stremyanny Lane, 117997 Moscow, Russia; pbio@ya.ru

6 Department of Applied Bioscience, College of Life and Environmental Sciences, Konkuk University, Seoul 05029, Korea; muthu@konkuk.ac.kr

7 Centro Tecnológico de la Carne de Galicia, avd. Galicia n ${ }^{\circ}$ 4, Parque Tecnológico de Galicia, San Cibrao das Viñas, 32900 Ourense, Spain

8 Área de Tecnología de los Alimentos, Facultad de Ciencias de Ourense, Universidad de Vigo, 32004 Ourense, Spain

* Correspondence: shariatymohammadali@gmail.com (M.A.S.); jmlorenzo@ceteca.net (J.M.L.)

\begin{abstract}
The consumer tendency towards convenient, minimally processed meat items has placed extreme pressure on processors to certify the safety of meat or meat products without compromising the quality of product and to meet consumer's demand. This has prompted difficulties in creating and carrying out novel processing advancements, as the utilization of more up-to-date innovations may influence customer decisions and assessments of meat and meat products. Novel advances received by the fish and meat industries for controlling food-borne microbes of huge potential general wellbeing concern, gaps in the advancements, and the requirement for improving technologies that have been demonstrated to be effective in research settings or at the pilot scale shall be discussed. Novel preparing advancements in the meat industries warrant microbiological approval before being named as industrially suitable alternatives and authorizing infra-structural changes. This miniature review presents the novel techniques for the microbiological safety of meat products, including both thermal and non-thermal methods. These technologies are being successfully implemented and rationalized in subsisting processing surroundings.
\end{abstract}

Keywords: thermal preservation; non-thermal preservation; cold plasma; ultrasound pulsed electric field; high pressure processing; ohmic heating

\section{Introduction}

The meat and fish processing industry is dynamic, and with increasing consumer concerns and demands, producers, processors, distributors and retailers all are now employing novel safety measures that will preserve meat quality and sustainability. Quality control and preservation of meat is more technical due to its perishable nature that provides a suitable medium for microbial spoilage. Therefore, with the developments in the 
food industry, advanced effective techniques are constantly adopted by the meat and fish processing industry especially to preserve quality and sensory attributes, which helps to maintain and expand the market. The preservation and consumption of meat requires adequate processing techniques to ensure microbial safety and maintain quality with extended shelf-life. With increasing competition and tighter cost margins, the meat industry is eager to engage in a search for novel innovative ways of processing meat, while maintaining quality and safety attributes.

Traditional techniques of the processing and preservation of meat and meat products are laborious, time-consuming, costly and require complex sample preparation. In this regard, meat processors are constantly looking for alternative, non-invasive techniques for meat quality assessment in an attempt to enhance productivity and profitability. Various research projects are investigating the novel processing and assessment technologies with their practical applications in meat industries globally. Whilst emerging technologies have demonstrated numerous advantages and potential for the food industry, there are limited commercial applications due to a number of factors. In some instances, industries have concerns about the adoption of new technologies due to a lack of knowledge or complexity of operational methods, but evidence suggests that novel technologies have more impact on product quality and safety than traditional methods. Currently, sustainability is defined along the three social-environmental-economic pillars, which are often referred to as triple bottom line or people-planet-profit [1].

Research databases relate food safety with the removal of pathogenic microorganism from food and separate it from the field of food spoilage prevention through microorganisms. Risk-based meat and fish inspection methods and safety guidelines are designed by the Food and Agriculture Organization (FAO) and include good hygiene and manufacturing practices (GHPs, GMPs), HACCP and other food safety laws and regulations [2]. Numerous countries' legislations have shown interest and support to this concept, but no clear differences are observed from a micro-ecological perspective. In spite of reported concerns, microbiological safety assurance systems are receiving more attention in developed countries. Food spoilage leads to various food-borne illnesses that can even cause death, resulting in economic losses [3]

Meat is one of the most perishable food commodities that is widely associated with food-borne diseases, as extensive outbreaks are associated with the consumption of contaminated meat and meat products [4]. The predominant pathogens responsible for meat-related outbreaks are Salmonella, Listeria monocytogenes, Bacillus cereus, C. botulinum, Shiga-toxigenic Escherichia coli, Clostridium perfringens and Staphylococcus aureus [4,5]. During the period of 1980-2015, most of the meat and meat product-related outbreaks were caused by Escherichia coli and Salmonella, with an incidence of 33 and 21 outbreaks, respectively. In E. coil outbreaks, out of the 1966 reported cases, 476 were hospitalized, 233 suffered from hemolytic-uremic syndrome (HUS) and 32 reported death. In Salmonella outbreaks, 2279 cases were reported, 94 were hospitalized, and 7 were reported dead [5].

Food spoilage results when microbiological, chemical, or physical changes occur, rendering the food product unacceptable to the consumer. Microbiological food spoilage is caused by the growth of microorganisms which produce enzymes that lead to objectionable by-products in the food. Chemical food spoilage occurs when different components in the food react with each other or with some added component which alter the food's sensory characteristics. Examples of this include oxidation, enzymatic browning, and nonenzymatic browning. Physical food spoilage results when moist foods are excessively dehydrated, or dried foods absorb excessive moisture.

Among all foods, fish is one of the most important commodities, which is popular all over the world due to its high nutritional value, being rich in proteins, vitamins and essential amino acids. In addition, fatty fish species are acknowledged as a natural food resource of omega-3 polyunsaturated fatty acids (PUFAS), such as eicosapentaenoic acid (EPA) and docosahexaenoic acid (DHA), which cannot be synthetized by the human body and must be included in the diet. 
However, fish is highly perishable with a short shelf-life and depends heavily on postharvest preservation methods, which is a challenge for the fish industry to avoid microbial spoilage while retaining high sensory quality parameters. Nowadays, consumers are conscious of healthy food products with enhanced safety, great nutritional value, premium sensory quality, apparent freshness and less or no chemical additives. To meet consumers' preferences, non-thermal food processing technologies, such as high-pressure processing (HPP), ultrasound (US), pulsed electric fields (PEF), pulsed light (PL), cold plasma (CP) and ozone have attracted extensive attention from the food industry as well as researchers. These technologies have been shown to be effective on the inactivation of spoilage and pathogenic microorganisms while maintaining nutritional and sensory properties for a wide range of food products, such as fruit and vegetables, fish, or fresh and ready-to-eat meat products [6].

\section{Factors Affecting Microbial Spoilage of Meat, Fish and Derived Products}

\subsection{Food Structure}

Food that is raw in nature remains protected from the attack of microorganisms due to the specificity of structures such as skin, shell, bran, etc. that are non-decomposable. These structures are attacked by specific species along with suitable enzymes (cellulase, pectinase, protease, etc.). However, meat and fish products are more susceptible to spoilage in their raw form due to suitable conditions for microbial spoilage. Surface contamination usually occurs at earlier phase of raw meat and fish processing. When the protective layer or packaging is removed, food tends to be more vulnerable to spoilage, which also speeds up the spread of microorganisms as soon as the processing phase starts. Meat spoilage is also based on meat moisture, $\mathrm{pH}$, animal age and health, temperature during slaughtering, processing and the packaging method of meat.

\subsection{Composition of Meat, Fish and Derived Products}

The growth of specific spoilage strains of microorganisms is supported by the nutrient composition of food. Proteolytic organisms have substantial potential to attack protein-rich foods, lipolytic organisms feed on fat-rich foods, while fermentative organisms are more liable to attack carbohydrate-rich foods [7]. Enzymatic degradation of lipids free fatty acids and produce derivatives such as aldehydes or ketones that cause rancid and unpleasant flavors and aromas in fat-based foods. Lipid decomposition mostly occurs in meat-based foods and oil groups such as olive oil derivatives. Naturally present antimicrobial substances and added inhibitory substances have the potential to control this spoilage in such foods [8]. For example, the egg albumin enzyme lysozyme has the potential to disrupt the cell walls of Gram-positive bacteria that can hydrolyze glycosidic bonds present in the peptidoglycan layer of the cell wall, while the avidin protein binds with biotin and forms conalbumin with iron and protease, which also limits protein degradation. Lactoferrin is also known as a natural inhibitor present in milk that seizes the iron needed for microbial growth, such as conalbumin which is found in eggs [9].

Commonly used antifungal compounds, such as citrate and nisin and butylated hydroxyanisol (BHA) and butylated hydroxytoluene (BHT), used as antioxidants act as inhibitors against microbial growth in meat, while the sorbates and benzoates show more sensitivity to bacterial growth. Various media concentrated with high sugar or salt content are considered as the preferred media for yeast growth; for example, Debaryomyces hansenii has more salt tolerance, while Hemimysis anomala and Candida pseudotropicalis has lower salt tolerance up to $25 \%$ and $11 \%$, respectively, in $\mathrm{NaCl}$ solution (w/v) [7]. Salting also helps to control the bacterial growth of Enterobacteriaceae spp. by reducing salted meat water content to $>0.9$ [10]. However, $3 \%$ salt addition has resulted in significant reduction in meat water activity to 0.95 , which will subsequently reduce the growth of pathogenic microorganisms such as Salmonella typhimurium, Staphylococcus aureus, Listeria monocytogenes and Bacillus spp. [11]. 


\subsection{Water Activity}

One of the main requirements of growth and metabolic activity for microorganisms is the availability of water. As meat and fish are perishable foods with water activity above 0.85 , the optimum ranges for the microbial growth is 0.995 to 0.980 . Microbial flora is based on nutrient availability and the available moisture content of foods. Psychotropic bacteria usually cause meat spoilage through various microbial activities. According to a USDA (2005) report, some of the common spoilage microorganisms of meat and meat products grow when the specific required $\mathrm{a}_{\mathrm{w}}$ is present in a particular product. Some examples of microorganisms include: Campylobacter, Pseudomonas, Salmonella, Clostridium botulinum, Listeria monocytogenes and Staphylococcus aureus, which have water activity 0.98, 0.97, 0.94, $0.96,0.92$ and 0.86 , respectively [12]. Some molds also cause spoilage even at a low water activity level, such as Xeromyces, which even survives at a low water activity of $\sim 0.6$, and $E$. coli at 0.95 . The spread of microbial growth can be controlled by lowering the water activity through various preservation methods, such as salting, syruping, drying and curing, that increase product shelf life [13].

\section{4. $\mathrm{pH}$}

The range of organisms that can cause spoilage of food are usually controlled by changing the $\mathrm{pH}$ of food [7]. At neutral $\mathrm{pH}$, microbial growth, especially bacterial growth, is observed more due to increased enzymatic activities. Normally, Lactobacillus spp. survives at 5.8-6.0 pH, but some studies have reported that few Lactobacillus strains also survive at 3.0-4.4 $\mathrm{pH}$ [9]; therefore, now, improved non-thermal techniques are adopted for stricter control. The $\mathrm{pH}$ of various food products can be lowered by various preservation methods, such as salting and pickling. Some proteolytic bacteria produce various amines during growth and metabolic activities that act as buffer and help to control the $\mathrm{pH}$ [14]. A reduction in $\mathrm{pH}$ below 6 and maintaining the temperature at $5{ }^{\circ} \mathrm{C}$ significantly controls the autolytic and catalytic reactions by controlling the $\mu$-calpain of muscle tissues in meat [15].

\subsection{Temperature}

Temperature is one of the critical factors that can limit the spoilage of perishable foods such as meat at all stages of processing, transport and storage. Increased temperature promotes bacterial growth, enzymatic activities and solute uptake, which will decrease the shelf life of food [13]. Various spoilage microorganisms grow to their maximum at their optimum growth temperature of 12 to $15^{\circ} \mathrm{C}$. Common spoilage microorganisms are E. coli, C. botulinum, S. aureus and Salmonella that spoil food and cause food-borne illness in human. The spoilage of meat can be controlled by lowering the temperature to $4{ }^{\circ} \mathrm{C}$ right after slaughtering for storage, and this is the case for processed meat products too [15]. Mold and yeast attacks on food are more severe as they not only easily grow at room temperature, but also in cool and chilled storage conditions [7]. the Spoilage of food due to spores of microorganisms both by bacterial and fungal spores is critical for control as spores are more resistant to high temperatures $\left(100^{\circ} \mathrm{C}\right)$ than microbial cells. Microorganisms can also be effectively controlled by rapid freezing due to the development of micro crystals [7].

\subsection{Atmosphere Conditions}

Microbial growth depends on oxygen surface tension and the oxidation reduction potential of food, which controls the nature of microbial flora. Aerobic bacteria usually grow in the presence of air and on the surface of some meat as there is sufficient oxygen available on the surface of the food product. Similarly, in mold spoilage, mold growth starts from the surface in aerobic conditions that later spreads inside food through its mycelium. Anaerobic bacteria, such as Bacillus, which can even grow in the absence of oxygen, critical to control their growth and spoilage activities in all foods, including both open and canned foods [7]. To control spoilage, oxygen is limited in stored meat by controlling air gas composition. Oxygen reduction to $5 \%$ can effectively control the microbial spoilage of meat and meat-based products [16]. Modified atmosphere packaging is one of the novel 
technologies used widely to stop aerobic spoilage. In modified atmosphere packaging (MAP), the oxygen environment can be changed with carbon dioxide, which helps to reduce spoilage.

\subsection{Interaction Phenomena}

Various physiochemical parameters have important roles in microbial growth due to their interaction with food components. Interactions may be positive or negative depending on various factors such as the type of food, microflora and the additives used during food processing or preservation. Microorganisms also have growth competition in a food product that supports all microbes (bacteria, yeasts, molds), then the bacterial growth is observed prominently. Some of the waste products produced by dominant microbes have the potential to control the growth activities of other microbes.

Similarly, spoilage microorganisms contribute their role in the inhibition, suppression or elimination of pathogen microorganisms in various food products. Some of the foodborne pathogens that can be suppressed by spoilage microbes are B. cereus, C. jejuni, C. botulinum, E. coli, L. monocytogens and Salmonella spp. Moreover, Pseudomonas and Shewanella putrefaciens and lactic acid bacteria also have the substantial potential to limit the bacterial pathogens' growth activities [17]. Lactic acid bacteria and yeast has a combined effect on Coliforms and Salmonella, while yeast also influences lactic acid bacteria [18].

Hurdle technology is an efficient approach in which various techniques of preservation are combined that have a better effect on microbial/spoilage control activities. Hurdle technology basically builds a barrier in conditions that support microbial growth. These hurdles can be created by varying growth parameters such as temperature, moisture, acidity, redox potential and by using various preservatives to improve microbial stability and sensory characteristics [19].

\section{Microbial Safety of Meat and Meat Products}

Food safety is a high need for wellbeing specialists and purchasers around the world. Meat, being the highest consumable food product that is an ideal vehicle for microbial development, has been brought to the front line. Health hazards correlated within meat items are of chemical, physical and biological types. Microbial agents may leads to serious health implications including $\mathrm{p}$ severe, mild, and chronic gastro-intestinal diseases. Therefore, various food safety and quality systems are being adopted in industries guaranteeing the wellbeing and safety of meat-based items [20].

A detailed technique for managing microbiological issues in meat items involves the execution of procedures or interventions that: (i) minimize or prevent transfer and access of microbes to the products; (ii) overcome starting contamination by inactivating or removing micro-organisms that have already gained access; (iii) kill or inactivate micro-organisms over products; and (iv) prevent or delay microbial growth that has received access or has not been disabled. Proper management and implementation of these approaches leads to the safety of meat products and minimally decreases the frequency of microbial meat-borne diseases. It is clear that updating food-related services or customer behavior should also ensure improved safety of meat and meat products [20,21].

Research has been conducted in recent years that there is nonstop variation and improvement in the opposition of pathogenic microorganisms to anti-microbials and possibly to conventional food safeguarding boundaries such as low $\mathrm{pH}$, heat, dryness, cold temperatures or minimum water activity, and other chemical preservatives. Moreover, there is proof of the presence of strains of pathogenic bacteria with upgraded capacity for endurance in their hosts, low infective dosages, and expanded destructiveness, now and then after exposure to basic environmental pressure [22].

\subsection{Spoilage Micro-Organisms of Meat}

The most predominant deterioration organic entities in meat are microbes, yeast and molds (Table 1). Because of the ubiquity of microorganisms, they are generally joined in 
meat from climate. These organic entities can cause decay by creating off smells in meat items. Bacterial spoilage of meat is more conspicuous when contrasted with other kinds, such as yeast and molds [20].

Table 1. Spoilage agents of meat and their impact on meat and meat product surfaces.

\begin{tabular}{|c|c|c|c|}
\hline Type of Micro-Organisms & Oxygen Need & Symptoms & References \\
\hline Aerobic Bacteria & Present & $\begin{array}{ll}\text { - } & \text { Discoloration of meat } \\
\text { - } & \text { Development of surface slime } \\
\text { - } & \text { Variation in smell } \\
\text { - } & \text { Decomposition of fat } \\
\text { Generation of gas }\end{array}$ & [23] \\
\hline Aerobic Bacteria & Absent & $\begin{array}{ll}\text { - } & \text { Generation of gas } \\
\text { - } & \text { Sour taste of meat products } \\
\text { - } & \text { Foul smell and putrefaction }\end{array}$ & [23] \\
\hline Yeast & Present & $\begin{array}{ll}\text { - } & \text { Development of surface slime } \\
\text { - } & \text { Occurrence of discoloration } \\
\text { - } & \text { Fariation in smell and taste } \\
\text { Famposition }\end{array}$ & [20] \\
\hline Molds & Present & $\begin{array}{ll}\text { - } & \text { Whiskery and sticky surface } \\
\text { - } & \text { Variation in smell } \\
\text { - } & \text { Decomposition of fat } \\
\text { - } & \text { Occurrence of discoloration }\end{array}$ & {$[24]$} \\
\hline
\end{tabular}

\subsection{Pathogens in Meat}

The predominant pathogen microorganisms are Salmonella, L. monocytogenes, B. cereus, C. botulinum, E. coli, $\mathrm{Cl}$. perfringens and S. aureus, while pathogenic spore formers are predominately $\mathrm{B}$. cereus and $\mathrm{Cl}$. perfringens.

\subsubsection{Listeria Monocytogenes}

L. monocytogenes has been accounted for in a few nations, and its rate relies upon dietary patterns, cooking techniques, utilization of refrigeration, and food importation. In light of openly accessible data at the time of the cases, the halfway expense of the listeriosis outbreak seen in South Africa (L. monocytogenes arrangement type 6 (ST-6) in 2017-2018 because of a colony was assessed at least USD 2.3 billion) added up to $0.82 \%$ of the Gross Domestic Product (GDP), with government reaction costing ZAR 65.5 million; in any case, the general effect figures are probably going to be lower considering a developing assemblage of better information quality [25].

\subsubsection{Salmonella Enterica}

Salmonella enterica was detected in Egypt at a percentage of 4.9 of beef samples. S. enterica serovar Typhimurium, S. enterica serovar Enteritidis, S. enterica serovar Infantis and non-typable serovars were also identified in various beef samples in range of 0.25 to $2.5 \%$. E. coli O157:H7 was recognized in $2.6 \%$ of hamburger tests. Shigella spp. were distinguished in $1.8 \%$ of hamburger tests. S. enterica serovar Infantis, S. enterica serovar Enteritidis, S. enterica serovar Typhimurium and non-typable serovars were recognized in $0.75 \%, 0.63 \%, 0.25 \%$ and $0.13 \%$ of chicken meat tests, respectively. E. coli O157:H7 and Shigella spp. were also identified in poultry meat at $\sim 0.5 \%$ and $0.25 \%$, respectively [26].

\subsubsection{Staphylococcus Aureus}

Other than Salmonella and Listeria, meat and its by-products are broadly known to be a significant repository for $S$. aureus and associated with various outbreaks. Therefore, 
the predominance and levels of $S$. aureus from South to North China were examined in retail meat and meat items. In this study, an aggregate of 1850 samples was gathered in 39 Chinese urban areas. By and large, there were 647 examples showing coagulase positive and which were affirmed for $S$. aureus. The normal occurrence of $S$. aureus was $35.0 \%$ $(647 / 1850)$. The dissected food items were ordered into three classifications (raw form meat, fast frozen meat, and ready-to-eat meat), and the upsides of $S$. aureus defilement in each sample were resolved. Among these classes, raw meat was the most often contaminated with $S$. aureus, with a pervasiveness that came to $51.0 \%$, including $60.9 \%$ of positive samples in fast frozen meat and $12.2 \%$ of RTE tests $[27,28]$.

\subsubsection{Clostridium Perfringens}

As of late, a few outbreaks of food poisoning, brought about by Clostridium perfringens, were segregated in meat and meat items. Clostridium perfringens is considered as one of the most significant food contamination microscopic organisms, which may allude to various deadly poisons, including the C. perfringens enterotoxin. This poison is liable for food contaminations linked with human gastrointestinal illnesses, causing gastrointestinal diseases of the bowels and stomach squeezing. [29]. A sum of 125 irregular raw and halfcooked chicken meat tests addressed by breast, thigh, chunks, panée and sausages were gathered from different retail locations and grocery stores in the Qualyubia governorate to examine the presence of $C$. perfringens bacteriologically. The results showed that 6 out of 25 raw breast samples (24\%), 8 out of 25 raw thigh tests (32\%), 5 out of 25 pieces tests $(20 \%), 4$ out of 25 panée tests $(16 \%)$, and 4 out of 25 sausage tests $(16 \%)$ were discovered to be contaminated with $C$. perfringens. Twenty-seven positive segregates obtained from these examples were recognized as $C$. perfringens dependent on the biochemical tests and microbial detection [30]

\subsubsection{Bacillus Cereus}

The group of Bacillus cereus, otherwise called B. cereus sensu lato, incorporates eight firmly related species: B. anthracis, B. cereus sensu stricto, B. cytotoxicus, B. mycoides, $B$. pseudomycoides, B. thuringiensis, B. toyonensis, and B. weihenstephanensis [31]. Research reported that in China, among the 603 meat and meat products, B. cereus was distinguished in 159 (26.37\%) samples, including 22.58\% (28/124) from hamburger, $26.73 \%$ (27/101) from chicken, 41.38\% (24/58) from ducks, 22.73\% (5/22) from sheep, and 25.17\% (75/298) from pork, while its levels in processed meat products $(41.94 \%)$ were observed as much more significant $(p=0.003)$ than raw samples $(24.58 \%)$ [32].

\section{Non-Conventional Techniques of Meat Preservation}

With expanding awareness and requests of customers for healthy, new and safe meat products, researchers are persistently occupied with creating and finding various imaginative and reformist food preservation procedures for expected commercial application. An immense scope of novel thermal and non-thermal meat handling and preservation advancements has acquired a lot of consideration over the course of recent years. The most accurately utilized strategies incorporate high pressure processing (HPP), radio frequency $(\mathrm{RF})$, pulse electric field (PEF), microwave innovation, ohmic heating, ozone processing (OP), utilization of ultrasonic waves, and adjusted and dynamic packaging techniques. A few advantages are aligned with the utilization of these strategies which incorporate high process proficiency, upgraded product quality, improved safety, and increased shelf life of meat items. In a similar manner, the current audit article features further headways in uses of these thermal and non-thermal strategies with extraordinary reference to meat handling and preservation [33].

\section{Thermal Preservation Technique}

Temperature control to below or over the ideal reach for microbial development has a preventive activity in microorganisms and is the most helpful, powerful, so-called "green" 
method for meat and meat product protection. Other than that, moderately mild heat practices, such as pasteurization, can be applied to inactivate most microorganisms without causing significant losses of organoleptic properties and meat nutrients. Growth and spoilage activities of Listeria monocytogen can be controlled at temperature ranges between $57{ }^{\circ} \mathrm{C}$ to $70{ }^{\circ} \mathrm{C}$. To accomplish all out lethality, sterilizing thermal treatment at $100{ }^{\circ} \mathrm{C}$ is utilized to inactivate every single vegetative cell, including pathogenic microorganisms, permitting cooked meat items to accomplish an undeniable degree of safety and soundness at room temperature. New thermal advancements have additionally been presented as potential heating strategies for meat, for instance, ohmic heating, dielectric heating, and radiofrequency heating [34].

\section{Novel Thermal Practices}

\subsection{Ohmic Heating}

Various trending strategies for the thermal treatment of meat or other food items have become obtainable, which has achieved the recommended degree of microbial decay with lower destruction to the organoleptic and nutritive characteristics of the meat, for, e.g., ohmic heating, dielectric heating, and radiant heating. The term ohmic heat is used to elaborate the direct electric heat resistance of food items. In the case of ohmic heating, a high temperature is created by flowing an electric current through the meat (which has huge resistance). The cycle allows continuous creation, without heat transfer, sterilization or pasteurization at moderately low temperatures. Therefore, damage brought about by heat as in the customary thermal practices is limited. This permits great maintenance of nutrition, just like the upkeep of the organoleptic attributes of meat, creating a high sensation of freshness and buyer fulfillment. Extreme electrical conductivity has been accounted for when beef meat filaments are lined up with the current flow stream, and the expansion of sodium chloride and phosphate, which increment the electrical conductivity, which brings about an increment in the ohmic heating rates and the nature/quality of cooked meat [35].

\subsubsection{Basic Principle of Ohmic Heating \\ Fundamentals of Electrical Circuitry}

The working for any electrical circuit is usually fabricated by the existence of three physical entities, namely amperage, voltage, or resistance. Volts (voltage) is an electric pressure contributed by the main AC supply, batteries, alternators, and generators. Resistance (i.e., ohms) is the opposition of the flowing current created by the circuits, e.g., wires, food or electrical components (whether in ohmic heating), whereas amperage (i.e., amperes) is the flowing current passed by the wires, electric components, and food. The mathematical equation between these three basic electrical sums (applicable in circuits with just resistive elements (i.e., no coils)) is the most significant, following the usual laws of electricity, or is called as Ohms law:

$$
\mathrm{V}=\mathrm{I} \times \mathrm{R}
$$

Here, $\mathrm{V}$ is the voltage or volts, $\mathrm{I}$ is the amperage or amperes, and $\mathrm{R}$ is the resistance or ohms $(\Omega)$ [36].

\section{Mechanism of Ohmic Heating}

In order to heat a material ohmically, it should be equipped for directing an electrical flow. For a material to be named as a conductor, electrical charges should have the option to move starting from one point then onto the next inside it to finish an electrical circuit. Meat and meat items, mostly containing high degrees of water, are viewed as solid materials. With regard to conducting electricity, solids, for example, metals, for the most part show metallic conduction because of the moderately free development of electrons through metallic grids. At the point when an electrolytic arrangement is put in contact with a couple of terminals to which a DC source is associated, versatile positive particles present in the item (for example Na1) move towards the negative electrode (cathode), and portable 
negative particles (for example $\mathrm{Cl}$ ) push toward the positive terminal (anode). At the negative terminal (which has an abundance of electrons), the positive particles receive electrons and are decreased, while at the positive anode (which has an insufficiency of electrons), the negative particles surrender electrons and are oxidized. In the event that the current inventory utilized in ohmic heating was DC, terminal polarization would quickly happen. Subsequently, to prevent this, AC current is utilized, as the cyclic change (for the most part low recurrence $50 \mathrm{~Hz}$ in Europe or $60 \mathrm{~Hz}$ in USA) in current heading permits deficient time for obvious polarization to happen as the electrochemical responses depicted above are viewed as undesirable in ohmic heating. As a further precaution measure against this event, anodes are frequently built from titanium or titanium covered with colloidal stores of "platinum dark" to work with the adsorption of the tiny amounts of terminal response items [37]. At the point when a meat product conducts power by electrolytic conduction, the moving particles inside it collide into different atoms, and these collisions lead to forcible movement of these atoms, which in turn expands their motor energy, accordingly heating the item. A study expresses that the cooperation between the local field strength and local electrical conductivity will administer the local generation of heat rate.

$$
\mathrm{Q}=\mathrm{E} 2 \mathrm{k}=\lambda \mathrm{J} 2
$$

Here, $\mathrm{Q}$ is the generated heat rate per unit volume $\left(\mathrm{W} \mathrm{m}^{-3}\right), \mathrm{E}$ is the electrical field strength $\left(\mathrm{V} \mathrm{cm}^{-1}\right), \mathrm{k}$ is the electrical conductivity $\left(\mathrm{S} \mathrm{m}^{-1}\right), \lambda$ is the resistivity $(\Omega \mathrm{m})$ and $\mathrm{J}$ is the current density $\left(\mathrm{A} \mathrm{m}^{-2}\right)$.

The actual heating rate for the substance is measured by the equation stated below:

$$
\mathrm{dT} / \mathrm{dt}=\mathrm{Q} /(\rho \mathrm{C})
$$

Here, $\rho$ is the density $\left(\mathrm{kg} \mathrm{m}^{-3}\right)$ and $\mathrm{C}$ is the specific heat capacity $\left(\mathrm{kJ} \mathrm{kg}^{-1}{ }^{\circ} \mathrm{C}^{-1}\right) . \rho \mathrm{C}$ is usually called as the volumetric heat capacity (i.e., the amount of heat energy that is needed to elevate the heat of one cubic meter of the substance by $1^{\circ} \mathrm{C}$ ) [38].

\section{Ohmic Heating in Meat Products}

The impact of ohmic heating on the textural properties of frozen ham cuts showed that ohmic defrosting brings about an item with a higher hardness and lower springiness than that of the regular strategy.

The various authors detailed that the applied voltage slope influences the textural properties of the thawed ham meat. As per TPA results, higher temperatures, more limited come-up occasions, and longer holding times brought about a milder surface. Additionally, ohmically cooked hams had a gentler and chewier surface than the customarily prepared example. Thermal processing adjusts the meat structure through cell layer obliteration, muscle strand shrinkage and protein denaturation, total and gel arrangement as well as connective tissue shrinkage and solubilization [39].

The expansion in temperature during ohmic heating $(\mathrm{OH})$ at $20 \mathrm{kHz}$ of conventional beef $(\mathrm{CB})$ and wagyu beef (WB) was assessed by examining the impacts on drip loss because of cooking, shrinkage and miniature structural changes. The impacts of equal and arrangement current headings, temperature $\left(5-65^{\circ} \mathrm{C}\right)$, recurrence $(50-20 \mathrm{kHz})$, and substance creation on the EC upsides of tests were assessed. A low drip loss because of cooking and shrinkage were found in both meats treated by $\mathrm{OH}$ at $23 \mathrm{kHz}$ and $50 \mathrm{~V}$. Expanding the recurrence caused a drop in obstruction and an expansion in heating rate, along these lines diminishing the heating time required for meat muscles, particularly for $\mathrm{CB}$, because of its high water and low fat content. Hence, the presence of fat decreases EC, bringing about irregular heating [40].

In another study, the combinations of pork meatballs and water were cooked utilizing a static ohmic radiator. The temperature of samples during heating were recorded and contrasted with model predictions. In addition, a few ascribes of ohmically heated meatballs were compared with those of conventionally heated samples. The outcomes demonstrated 
that Sukprasert's model was the most exact; in any case, the precision of the limited difference model would be practically identical if the model was added with observational terms. The electrically produced heat and the convective heat moved between stages were persuasive to the sample temperatures during ohmic heating. The ohmically heated meatballs were altogether firmer and more uniform in microstructure and more splendid in color than their counterparts, though their moisture percentage was lower [41].

Ohmic heating can be utilized as an elective warming strategy for fast cooking of meatballs. The heat produced by the electrical field and the convective heat transfer between the meatball and water were powerful at the sample temperatures during ohmic warming. Both non-uniform conveyance of electrical field inside the mixture and the underlying changes in meatballs during ohmic cooking were expected to be crucial reasons for the predicted error of the hypothetical models. Additionally, the variations in heating method and heat rate may leads to the changes in the characteristics of meatballs. The consistency of temperatures inside the sample during ohmic heating is the vital justification of the contrasts between the traits of conventionally and ohmically cooked meatballs $[39,40]$.

\subsection{Radio Frequency $(R F)$}

High-frequency heating, which incorporates radiofrequency (RF) and microwave (MW) warming, has acquired expanded industrial interest and shown extraordinary potential to turn into the options in contrast to conventional techniques for heat processing [1]. Radio frequency is viewed as a volumetric type of heating which accomplishes speedier cooking times and can possibly prompt more uniform heating because of dielectric energy. Dielectric energy prompts molecular friction in water particles to create heat, which is incompletely reliant upon the moisture content of food. RF has assigned frequencies approved by the U.S. Federal Communication Commission (FCC) for modern heating, with $13.56,27.12$, and $40.68 \mathrm{MHz}$ as the radio frequency range (Table 2).

Table 2. Differentiation of major properties between radio frequency (RF) or microwave heating in the food industry [24].

\begin{tabular}{ccc}
\hline Properties & Radio-Frequency & Microwave \\
\hline Work frequency & $13.56,27.12,40.68 \mathrm{MHz}$ & $915,2450 \mathrm{MHz}$ \\
In vacuum wavelength & $22.1,11.1,7.4 \mathrm{~m}$ & $0.33,0.12 \mathrm{~m}$ \\
In tap water (penetration depth) & $1.58,0.79,0.53 \mathrm{~m}$ & $0.02,0.01 \mathrm{~m}$ \\
Prime heating mechanism & Migration of ionic charge & Dimple \\
System construction & Complicated \\
\hline
\end{tabular}

\subsubsection{Heating Mechanism of Radio-Frequency}

Dielectric characteristics are the intrinsic assets of substance discussing the degree of a material's interactivity with an oppositional electrical field, and determining its reflecting ability, storing, or transmittance electromagnetic wave. The dielectric properties can be expressed as

$$
\varepsilon *=\varepsilon^{\prime} \mathrm{j} \varepsilon
$$

where $\varepsilon *$ is the complex comparative with (vacuum) permittivity; $\varepsilon^{\prime}$ is the overall dielectric steady, which is a proportion of the capacity of a material to store electromagnetic energy; $j$ is the imaginary unit; and $\varepsilon=$ is the general dielectric loss factor, which is a proportion of the capacity of a material to disseminate electromagnetic energy into heat. Numerous elements influence the dielectric properties of a material, such as frequency, temperature, and food organization and thickness [24].

\subsubsection{Application of Radio Frequency in Meat Products}

As per different examinations, the impact of fat level, both with and without the expansion of salt, on the cooking design and physicochemical properties of ground pork patties cooked by microwave energy has been found. The authors observed that tempera- 
tures at the edge of the pork patties expanded quicker than those at the middle or in the mid-manner positions inside the microwave cooker. Absolute cooking loss, drip loss, and the decrease in diameter or thickness were higher in patties with $20 \%$ fat contrasted with those with $10 \%$ fat content, along these lines demonstrating the impact of fat substance and salt on cooked meat utilizing microwave energy. The radio waves has longer wavelength and low frequency as compared to microwaves thus enabling them to penetrate deeply in to product resulting in the uniform heating.In this sense, RF is more reasonable and powerful for huge breadth staples such as meat items [1,42].

Obviously, the nature of heated items by RF turns into the critical factor. Liu, W. and colleagues, 2016, explored the impact of RF heating on the color, water holding limit, and surface of three kinds of meat items (comminuted, ground or muscle). Their examination tracked down that the edible nature of some meat items was unfavorably influenced, particularly the texture [43]. Different authors compared the quality of meat items prepared by RF heating and steam heating. Curiously, they found that meat warmed by RF had more enthusiastic consistency than that heated by steam. Additionally, specialists had the option to recognize RF-cooked and steam-cooked samples. Regarding time, a shorter cooking time of the hams was needed with RF cooking [44]. Despite the fact that reviews have discovered that RF cooking enjoyed benefits of a more limited cooking time, decreased juice loss, and satisfactory color and surface, the viability of RF cooking on the inactivation of E. coli in ground hamburger has made a correlation between the timeframe of realistic usability of ground meat cooked by RF and that by heated water bath. They discovered that the two strategies were powerful in lessening microbial defilement; in any case, RF heating required a more limited cooking time and brought about more uniform heating, and along these lines, the RF cooking of meat is best in the meat industry [1].

\section{Non-Thermal Preservation Techniques \\ 6.1. Cold Plasma}

Plasma is an ionized gas that contains atoms or molecules in a metastable state with a net electrical charge of approximately zero. Plasmas can be caused in any neutral gas by supplying enough energy to cause ionization of the gas [45]. Cold plasma is a source of high-energy electrons that interact in an open or controlled environment at ambient temperature and pressure [46]. When an electrical energy source is applied to a gas, many reactive species, such as ultraviolet photons, charged particles, radicals, and other reactive nitrogen, oxygen, and hydrogen species, are generated [47]. Cold plasma treatment is a successful food processing intervention for improved product protection and extended shelf life. Enabled cold plasma chemical species will quickly function at ambient temperatures against microorganisms without leaving any known chemical residue. In certain sites of a fungal cell, cold plasma species interact and result in a loss of function and structure and, eventually, cell death. The sun is a good example of thermal (hot) plasma at very high temperatures. A low-temperature plasma (cold) example is polar light [45]. Plasma ROS interacts harmfully with essential cell biomolecules, including DNA, proteins and cell enzymes. ROS can change biological membranes' function by interactions with lipids, causing the formation of unsaturated fatty acid peroxides in proteins and the oxidation of amino acids [48]. If the cell membrane of the bacterium is exposed to strong electric fields, it can be ruptured because of the electrostatic stress caused by the electrical charge that develops internally. Inactivation effects are subject to many factors, including plasma sources, operating conditions, gas used, the existence of the product/substratum and the microorganism itself [48]. Spoilage of raw meat is commonly associated with the growth of certain psychotropic bacteria, especially when the product is chilled and stored in aerobic conditions. The plasma jet, based on $\mathrm{He}+\mathrm{O}_{2} \mathrm{DBD}$ (dielectric barrier discharge), reduced the total bacteria count on chicken skin effectively and increased efficacy over time. E. coli and L. monocytogenes are the most resistant human pathogens in meat and meat products [48]. The use of an atmospheric plasma jet operating in $\mathrm{He}, \mathrm{He}+\mathrm{O}_{2}, \mathrm{~N}_{2}$, or $\mathrm{N}_{2}+\mathrm{O}_{2}$ to treat L. monocytogenes inoculated on cooked chicken breast and ham was found 
to be successful in extending the shelf life of the products [49]. In meat and meat products, color and texture are essential physical qualities [48]. The treatment of pork and beef with flexible thin-layer DBD plasma with increased plasma treatment exposure time resulted in a reduction in redness [50]. Chicken breast treated with flexible DBD showed a reduction in redness and an improvement in lightness [51]. If myoglobin reacts with $\mathrm{H}_{2} \mathrm{O}_{2}$ (hydrogen peroxide) to form choleglobin, meat discoloration can occur during plasma treatments [48]. In contrast to color, there are no discernible variations in texture between pork and beef loin. Similar scores for appearance, color, odor, and overall acceptability, but not taste, have been recorded in cooked pork and beef treated with DBD plasma when compared to the control [49]. In chicken breasts treated with flexible DBD, the production of some off flavors has been reported [51].

Cold plasma technology has been widely adopted to control the microbial growth of pathogens such as Campylobacter jejuni by employing feed gases for $30 \mathrm{~s}$ to $180 \mathrm{~s}$ at a 5-12 mm distance from the plasma heat source that increased the surface temperature to $61{ }^{\circ} \mathrm{C}$, resulting in a $1.42 \mathrm{CFU} / \mathrm{cm}^{2}$ reduction [52]. Similarly to other technologies, the concept of hurdle technology is applied in the cold plasma method. In this method, atmospheric cold plasma has been applied with peracetic acid resulted in a significant reduction in Salmonella load to a maximum of $5.3 \log \mathrm{CFU} / \mathrm{cm}^{2}$ [53]. Cold plasma technology also has substantial potential against common food-borne pathogens such as Salmonella, Listeria and the Tulane virus. For Salmonella inactivation, about $39 \mathrm{kV}$ energy for $3.5 \mathrm{~min}$ was found to be significant in the reduction in load to about 3.7 CFU/cube [54]. Cold plasma treatment at $70 \mathrm{kV}$ was applied for various periods on packaged meat at $4{ }^{\circ} \mathrm{C}$ and showed effective inactivation against Salmonella and campylobacter spp. and improved the meat's sensory characteristics [55].

\subsection{Ultrasound}

Ultrasound is a new technology which has a variety of food processing applications. The sound wave could be defined as higher than the waves that human ears perceive [56]. However, US frequencies above $20 \mathrm{kHz}$ are not audible [57]. Ultrasonic treatments (US) are classified as non-thermal and are used between $20 \mathrm{kHz}$ and $1 \mathrm{MHz}$ in food processing. Cavitation bubbles are produced when the US intensity is strong enough to cause rarefaction that is greater than the medium's intermolecular attraction forces [58]. Ultrasound was first used in the meat industry to assess the fat and muscle of live cattle, and this has been going on since the 1950s. Low-intensity ultrasound is now commonly used to improve quality, taste, and tenderness, which are the three most important quality attributes in terms of customer satisfaction. Many recent studies have suggested that high-intensity ultrasound could be used on fresh meat [59]. US use is currently common in the meat industry to improve meat tenderization, bulk emulsification, marination, frostbite, homogenization, crystallization, drying and inactivation of the microorganism. Since both Escherichia coli and Salmonella are susceptible to US, it can be considered a new green technology for tenderizing and decontaminating poultry meat. US improves the physical and chemical properties of meat proteins, resulting in a decrease in the $\alpha$-helix in the intramuscular protease complex as well as lower viscosity coefficients. As a result, ultrasonic treatment can be used to improve the texture of chicken meat. In comparison to other traditional techniques, US can also improve drying rates under vacuum. US can be used at a high frequency $(>1 \mathrm{MHz})$ with low intensity $\left(<1 \mathrm{~W} / \mathrm{cm}^{2}\right)$ or low frequency $(20-100 \mathrm{kHz})$ with high intensity $\left(10\right.$ to $\left.1000 \mathrm{~W} / \mathrm{cm}^{2}\right)$, depending on the application in food processing [44]. US has the ability to modify cell membranes in meat processing, which can aid in curing, marinating, drying, and tenderizing tissues [60].

Ultrasound curing improves brine transfer into meat, decreases processing time, and improves product quality [61]. The use of an ultrasonic bath at $40 \mathrm{kHz}$ and $110 \mathrm{~W}$, as well as sodium chloride (in marinating for longer periods of time) resulted in increased meat hardness, weight loss, and changes in color parameters (lightness and redness), but also reduced WHC, water content, and $\mathrm{pH}$ [62]. Chicken meat treated with a US probe $(22 \mathrm{kHz}$, 
$27.6 \mathrm{~W} / \mathrm{m}^{2}$ ) was found to reduce the number of mesophilic bacteria [63]. US treatment may have a lower discoloration effect in poultry as compared to red meat. When compared to control meat, the color of ultrasonic-treated beef meat at an intensity of $22 \mathrm{~W} / \mathrm{cm}^{2}$ showed less redness, less brightness, and a more yellow/orange color [64]. The antimicrobial efficiency of high-intensity ultrasound is dependent on several factors, including the duration of contact with the microorganism, the nature of the microorganism, the amount and composition of food, and the treatment temperature [65]. Gram-positive bacteria are more resistant to ultrasound because their cell walls are thicker, due to a coating of peptidoglycans that protects them from sonication. Cell morphology is indicated as a major factor because coccoid cells demonstrate higher tolerance than spores of bacillus bacteria to acoustic activity. Spoilage by spores of Clostridium and Bacillus species are more resistant to ultrasonic treatment than vegetative cells [59]. Oxidative stability, meat color and sensory characteristics are important factors during meat ultrasonication. The use of sound energy can accelerate the process of meat thawing. The quality of the meat is enhanced by the implementation of ultrasound to reduce the time of meat brining [65]. Difficulty in choosing the right parameters for the desired product (i.e., pressure, time, temperature, strength, power and amplitude) and the production of free radicals (adversely affect the product quality because of oxidation) are some of the drawbacks of US treatment [66].

The application of ultrasonic treatment to reduce microbial count in meat was assessed against E. aerogenes and B. subtilis and resulted in effective reduction to $4.5 \mathrm{log}$. The study also concluded that a constant ultra-sonication treatment to meat for about 20 min with 13 Watts of power is effective against most of the bacteria. Ultrasound at a frequency of $40 \mathrm{kHz}$ and intensity with $9.6 \mathrm{~W} / \mathrm{cm}^{-2}$ for maximum of $50 \mathrm{~min}$ for about 7 days effectively reduced the number of almost all kinds of psychrophilic and mesophilic bacteria, while oily fish high in fat content showed more reduction in microbial count for 5-45 min at $30 \mathrm{kHz}$. However, for E. coli, $10 \mathrm{~min}$ of exposure to ultrasonic treatment reduced viable cell counts up to $100 \%[44,67]$.

\subsection{Pulsed Electric Field}

Pulsed electric field (PEF) is a new non-thermal technology that has recently attracted meat scientists' and technologists' interest because it is capable of modifying the membrane's structure and increasing mass transfers through PEF [68]. Short electrical pulses at high voltages allow thermal effects to be regulated and kept low, distinguishing it from thermal electrical-based approaches such as ohmic heating and moderate electrical field [69]. The PEF technique interrupts biological cells in the food matrix without disrupting the product's attributes [70]. Electric field pulses of short duration (several nanoseconds to several milliseconds) with electric field strengths of $0.1-80 \mathrm{kV} / \mathrm{cm}$ are applied to food that is placed between or passed through two electrodes in PEF technology [71,72]. PEF can modify various qualitative characteristics of meat, such as texture, color and water holding capacity, and improve processes of mass transfer such as curing and brining [70-73]. PEF processing in meat technology focuses on meat protection, tenderization, super cooling, and rapid brining, among other things, because of its capacity for permeabilization of cell membranes [68]. The temporal flavor profiles of meaty and oxidized flavor attributes were found to be influenced by PEF treatment [74]. During PEF processing, temperature rises from $5{ }^{\circ} \mathrm{C}$ to $30{ }^{\circ} \mathrm{C}$ due to moderate ohmic heating have an impact on meat quality [68]. Browned, juicy, livery, and meaty flavor attributes were found in all PEF-treated samples. Some of the terms associated with "positive" attributes include meaty, roast beef, juicy, browned, fatty, and salty. PEF-processed meat at $1.1-2.8 \mathrm{kV} \mathrm{cm}^{-1}$ showed no significant improvement in the tenderness of meat during storage [75]. PEF treatment results in a significant increase in beef tenderness when treated at 5-10 kV [76]. Beef treated at 5-10kV at different frequencies 20,50, and $90 \mathrm{~Hz}$ showed up to a $19 \%$ reduction in shear force [77].

In a recent research database, PEF employed for bacterial growth prevention with a $280 \mathrm{mHz}$ frequency of pulse electric field strength with $300 \mathrm{~V} / \mathrm{m}$ applied, which resulted 
in the inactivation of the bacteria Yersinia Enterocolitica present in beef and prolongs the storage period to 30 days at $-20{ }^{\circ} \mathrm{C}$ [75].

\subsection{Irradiation}

Irradiation involves applying low-level energy radiation to the material [78]. Irradiation is an electric energy emission to waves or ionizing moving particles if it has adequate energy to remove the electrons from the atom or molecule [79]. The USDA and FDA have approved food irradiation since 1989, and around 30\% of countries around the world have adopted it as a commercial method of food preservation, followed by the United States, China, the Netherlands, Belgium, Brazil, Thailand, and Australia [80]. Under the new FSSAI regulations in 2016, the irradiation of foods is now called 'Radiation processing of food'. The benefits of this technology include the fact that it is a physical, cold, and nonadditive process that results in minimal food changes. The ultrasound method is highly effective when compared to chemicals and fumigants and can be used on pre-packaged food. A rise in the occurrence of food-borne diseases, especially those of animal origin, has been observed in both developed and developing countries [81]. Gamma rays, X-rays and electron beams are radiation sources that can be used to irradiate foodstuffs [82]. Gamma rays, X-rays or electrons can lead to electrons being released from their orbits and producing ions. Free electrons collide to create a radical electron beam. The ionizing mechanism of radiation may disrupt the chemical bonds of DNA and other biomolecules and hence interrupt cell insect infestation. Radioisotopes of Cobalt-60 and Cesium-137 are permitted in foodstuffs for gamma radiation. Machines using the electricity to produce electrons beam up to $10 \mathrm{MeV}$ [79]. X-rays with up to a $5 \mathrm{MeV}$ energy level are allowed in foodstuffs; however, radiation from X-rays is expensive [78]. The wavelength of the $\mathrm{X}$-ray is below $100 \mathrm{~nm}$. It requires no radioactive source, has a high penetration rate and a high dosage reliability. X-rays have extremely short wavelengths from 8-12 $\mathrm{m}$ and a high frequency from 1016-1020 Hz [79]. The X-ray (high-energy particulate matter) produced by the radiation source machine has an energy level of 5 to $10 \mathrm{MeV}$, which can be used for food irradiation. X-rays can penetrate $30-40 \mathrm{~cm}$ into thick materials, with this property allowing them to be used in packed products [83].

One of the most serious issues is the microbiological safety of irradiated foods. The macronutrients are unaffected; however, certain vitamins may be affected. Irradiation doses should not exceed the recommended dose, which is $10 \mathrm{KGy}$ [84]. Irradiation between $1-10 \mathrm{kGy}$ is a documented method for lowering the microbial load in foodstuffs. Salmonella, Listeria, and other pathogenic bacteria can contaminate poultry, meat, and eggs. UV (ultraviolet) rays are a form of non-ionizing radiations that can be used to kill pathogenic microbes with a wavelength of $100-400 \mathrm{~nm}$, which is shorter than the wavelength of visible light, 400-700 nm [85]. The irradiation of fresh meat and meat products is thought to be a healthy and reliable way to prolong their shelf life. The Food and Drug Administration (FDA) has approved the use of irradiation to contain food-borne pathogens and extend shelf life in poultry and red meat [81]. Irradiation is a successful preservation technology; however, its use in meat and meat products causes physicochemical and biochemical changes that affect nutritional and sensory properties. Radiation processing of muscle foods produces free radicals and accelerates lipid and protein oxidation, resulting in negative changes. Ionizing radiation produces free radicals, which promote lipid peroxidation and other changes while also influencing meat sensory quality [81]. Beef treated at a temperature of $20{ }^{\circ} \mathrm{C}$ with a $2 \mathrm{kGy}$ dose of radiation with a modified air package did not lead to additional oxidation [86]. The factors influencing irradiation oxidation of meat products are mainly the composition, storage and packaging of fatty acids and the proportion of polyunsaturated fatty acids. The oxidation of lipids leads to hydro peroxides, aldehydes, ketones and various other products which affect taste, flavor, nutritional profile and acceptable conditions [87]. Irradiation also affects the color of the meat due to the susceptibility of iron in myoglobin, the main meat pigment. Myoglobin is adequately destroyed at a dose of $50 \mathrm{kGy}$ or higher [86]. The optimal color of meat can be preserved 
during the irradiation process by pre-slaughter antioxidant feeding, antioxidant addition, packaging technique, and appropriate temperature. Irradiation at a high dose results in unacceptable off odors and meat discoloration, whereas irradiation at a low dose results in fewer odor, flavor, and color issues [86].

Applications of irradiations in meat and fish at various wavelengths, such as $1.68 \mathrm{mWs} / \mathrm{cm}^{2}$ for $140 \mathrm{~s}$ in shredded bullfrog, in chicken $1.95 \mathrm{~mW} / \mathrm{cm}^{2}$ for $120 \mathrm{~s}$, fish meat $55.83 \mathrm{~mJ} / \mathrm{cm}^{2}$ and in beef at $164 \mathrm{~mJ} / \mathrm{cm}^{2}$, showed significant results. In fish and meat products such as chicken breast, fish fillets and beef, etc., microorganisms such as Murine norovirus1, Hepatitis A virus and Enterobacteriaceae load were significantly reduced $[87,88]$. In a database, the chicken meat microbial load reduction in the norovirus and hepatitis virus was 1.23 and 1.17 PFU/mL, while in fish, a microbial load reduction in various psychrophilic, mesophilic and enterobacteriaceae was observed significantly to levels of $0.26,0.25$ and $0.15 / \mathrm{g}[87,89]$.

\subsection{Pulsed Light}

Pulsed light (PL) is a technique that uses short light pulses to inactivate microorganisms on food surfaces. The UV spectra of light is responsible for the antimicrobial effect, as it damages the DNA of microorganisms [90]. In the PL treatment, 1-20 light flashes per second with energy ranging from 0.01 to $50 \mathrm{~J} / \mathrm{cm}^{2}$ are used [91]. The microorganisms on the surface of the food and the packaging material are inactivated by these pulses. UV light causes physicochemical changes in microbial DNA, which damages the genetic information and leads to impaired replication and gene transcription, as well as cell death of microbes [90]. There are various potential uses in the meat industry, such as carcass (skin and meat) decontamination, better safety of fresh food products such as beef and tuna carpaccio, decontamination of knives and equipment after contact with meat and meat products, as well as sliced fermented sausages. Pulsed light intensity can cause changes in the sensory properties of meat, particularly color and aroma.

There are some limitations to the treatment's intensity, which should be optimized based on the number of flashes, voltage, spectral range, and distance between the product and the light source. Another concern is the financial aspect due to the requirement for specific equipment [90]. After PL treatments, the initial microbial count was reduced by approximately $2.0 \log$ CFU/mL. Listeria monocytogenes and Salmonella enterica were the most commonly studied microorganisms in fish after PL treatments. The L. monocytogenes count was reduced by 0.9-2.24 log CFU/mL in meat and 0.7-2.4 log CFU/mL in fish/seafood, whereas S. enterica had a value of $2.0 \log \mathrm{CFU} / \mathrm{mL}$ [91]. PL treatments $(0.7,2.1,4.2,8.4$, and $11.9 \mathrm{~J} / \mathrm{cm}^{2}$ ) were used to improve the safety of beef. The results showed a considerable reduction in the initial microbial count $\left(1 \log \mathrm{CFU} / \mathrm{cm}^{2}\right)$ of samples inoculated with Vibrio parahaemolyticus, E. coli, L. monocytogenes, and Salmonella Typhimurium after PL treatment at 8.4 and $11.9 \mathrm{~J} / \mathrm{cm}^{2}$, as well as a marked enhancement in the food safety of beef [92]. It was also observed that PL treatment was equally efficient in inactivating all pathogens inoculated on the surface of fermented salami slices (E. coli O157, Staphylococcus aureus, L. monocytogenes, and Salmonella spp.), with a highest possible inactivation of microorganisms of $2.2 \log$ CFU/g [93]. The changes in meat sensory quality caused by PL varies widely depending on the species of animal, type of meat, and PL dose used. PL had little effect on the sensory properties and instrumental color values of dry cured and fermented meat products [92].

Pulsed light is specifically used for microbial spoilage control in meat and pork. Evidence has reported that pulse light application in range of 0.52 to $19.11 \mathrm{~J} / \mathrm{cm}^{2}$ caused a significant load reduction in Salmonella Typhimurium count ranging from 1.73 to $3.16 \log$ reduction, while for Yersinia enterocolitica, load reduction ranged from 1.48 to $4.37 \log$ [94].

\subsection{High Pressure Processing}

Until now, the most successful alternative non-thermal technology in the food industry was High-Pressure Processing (HPP) [95]. Food products represent an important market 
share for the use of HPP in the food industry, with meat products representing 25 to 30 percent of the total foods processed under high pressure (HP). Therefore, over the period between 2013 and 2016, the number of HPP units in industrial operations doubled from 215 to 430 HPP units [96]. HPP is used in several other finished meat products as an efficient way to inactivate and monitor pathogenic bacteria such as Listeria, Salmonella, and E. coli, avoiding food-borne contamination and outbreaks.

HPP has numerous advantages to ensure food safety and has significant and unique value for the industry. HPP can impact the labile nature of proteins, especially in fresh meats, when used under certain processing conditions, such as temperature $[\mathrm{T}]$, pressure $[\mathrm{P}]$, and time [t]. HPP has moderate to serious negative impacts on the meat appearance and other quality features depending on the applicable conditions, which is why wide implementation of HPP technology in the meat industry is very limited [95]. High-pressure processing requires pressures of at least $100 \mathrm{MPa}$, with the most common range being 100-1000 $\mathrm{MPa}$, and can work in temperatures ranging from $-20{ }^{\circ} \mathrm{C}$ to $90{ }^{\circ} \mathrm{C}$. At certain temperatures for appropriate time and pressure levels, non-covalent bonds, such as hydrogen bonds, ionic bonds, and hydrophobic bonds, are destroyed. Enzymes, proteins, starch and other molecular biological substances are deactivated, denatured and gelatinized, respectively, and microbes will be killed for the sake of food safety and preservation [97]. During the HPP process, the $\mathrm{pH}$ of meat will decrease, and pressure level, treatment time and temperature, muscle type, and meat temperature are some main factors which effect the high level of $\mathrm{pH}$ in meat. After being subjected to high pressure, the fresh meat witnessed a rapid fall in $\mathrm{pH}$ and an intense contraction. The red meat $\mathrm{pH}$ decreased by $0.6-0.8$ units after 100-150 $\mathrm{MPa}$ pressure for $1-5 \mathrm{~min}$ at $35^{\circ} \mathrm{C}$. However, the $\mathrm{pH}$ of white meat reduced more significantly after 10 min of pressurization [97]. It is observed that the WHC of yak meat is increased and then decreased with an increase in pressure and processing time. A total of $10.50 \%$ WHC increased, and meat color changed into white at $250 \mathrm{MPa}$ pressure for $15 \mathrm{~min}$ [98]. Myoglobin is the largest meat pigment and accounts for $90-95 \%$ of the total pigment content of meat, chemical-physical and concentration state of myoglobin in fresh and processed meat have a major step in color.

Color changes in meat in HPP depends primarily on three primary factors: (1) denaturation of myoglobin, (2) modification or disruption of the porphyrin ring, and (3) changes in the myoglobin redox chemistry. At pressures below $300 \mathrm{MPa}$ and low temperatures, HPP creates slight color changes then high pressure; however, the denaturation of myoglobin occurs at a low pressure due to its instability. High-pressure treatment could alter muscle microstructure, sarcomere contraction, muscle fiber damage, and myofibril fragmentation by hydrolyzing muscle fiber proteins, weakening cell structure, releasing ions, and activating calcium-activating enzymes [97]. When compared to traditional thermal processing, HPP has the following advantages: shorter processing times; minimal heat penetration/heat damage issues; excellent freshness, flavor, and color retention; no vitamin C loss; and minimal functionality changes, avoiding chemical additives or high temperatures in order to meet consumer demand without causing consumer dissatisfaction. Microorganisms and enzymes can be inactivated at low temperatures, while highly valued low molecular constituents such as bioactive components, vitamins, colors, and flavorings are largely unaffected [99].

In recent years, the integration of natural antioxidants and antimicrobials in the polymer matrix has gained significance to increase the efficacy of HPP in extending the shelf-life of meat products as an innovative multi-hurdle approach. Recent research has shown that developing active packaging in combination with high-pressure processing is a promising multi-hauled approach for completely eliminating food-borne pathogens in RTE meat products during refrigerated storage. Moisture absorbers, carbon dioxide emitters, and oxygen scavengers are some of the other important active packaging concepts [100].

The application of the above-discussed techniques alone and in combination has a potential effect in controlling microbial spoilage and improving meat shelf life, along with 
the quality not only of raw meat but also has a significant effect on ready-to-eat meat products [101].

\section{Conclusions}

Numerous food preservation techniques are being employed in meat and fish industries to ensure their safety and shelf-life extension. The main focus of this manuscript is to highlight the impact of novel techniques such as ohmic heating, irradiation, pulsed-electric filing, cold plasma, ultrasound and high-pressure processing on meat safety with compromising nutritional attributes. Non-thermal techniques also permit great maintenance of nutrition and organoleptic attributes of meat and meat-based products and maintain freshness and quality characteristics. Reviews have concluded that these novel non-thermal techniques also limit cooking time, juice loss reduction, and satisfactory color and surface. In meat and fish products, color and texture are essential physical qualities with DBD plasma with increased plasma treatment exposure time, resulting in a reduction in redness. Cold plasma treatment is a successful food processing intervention for improved product protection and extended shelf life by controlling spoilage microorganisms without leaving any known chemical residue. In certain sites of a fungal cell, cold plasma species interact and result in a loss of function and structure and, eventually, cell death. Similarly, ultrasound use is currently common in the meat industry to improve meat tenderization, bulk emulsification, marination, frostbite, homogenization, crystallization, drying and inactivation of all microorganisms, such as E. coli and Salmonella. PEF also ensures the quality parameters of meat, such as texture, color and water holding capacity, which improve the overall characteristics in common preservation methods of curing and brining. Similarly, HPP is also effective in the reduction in processing times, minimal heat penetration to promote freshness, flavor, and color retention. Limitations in employing these techniques are their complexity and cost due to expensive systems. Meat technology focuses on meat protection, tenderization, super cooling, and rapid brining for preservation of optimal meat color by pre-slaughter antioxidant feeding, antioxidant addition, packaging technique, and appropriate temperature for long-term use by optimizing novel non-thermal systems at the industrial level.

Author Contributions: Conceptualization, M.F.J.C., S.T. and M.R.; writing-original draft preparation, T.M., A.K., J.M.L. and S.T.; writing-review and editing A.D., A.S., M.K., S.B., M.A.S. and M.T.; supervision, M.R.; project administration, M.R. All authors have read and agreed to the published version of the manuscript.

Funding: This work was supported by the Ministry of Science and Education of the Russian Federation (Grant Agreement 075-15-2020-775).

Institutional Review Board Statement: Not applicable.

Informed Consent Statement: Not applicable.

Data Availability Statement: The data may be available upon request.

Acknowledgments: The authors are highly thankful to the Department of Food Science and Technology for the contribution and all authors agreed to publish this final version of the manuscript.

Conflicts of Interest: The authors declare that they have no conflicts of interest.

\section{Abbreviations}

$\begin{array}{ll}\text { FSO } & \text { Food Safety Objectives } \\ \text { HACCP } & \text { Hazard Analysis and Critical Control Point } \\ \text { GDP } & \text { Gross Domestic Product } \\ \text { S. aureus } & \text { Staphylococcus aureus } \\ \text { RTE } & \text { Ready To Eat } \\ \text { HPP } & \text { High Pressure Processing }\end{array}$




$\begin{array}{ll}\text { RF } & \text { Radio Frequency } \\ \text { PEF } & \text { Pulse Electric Field } \\ \text { CB } & \text { Conventional Beef } \\ \text { WB } & \text { Wagyu Beef } \\ \text { OH } & \text { Ohmic Heating } \\ \text { EC } & \text { Eddy Current } \\ \text { DC } & \text { Direct Current } \\ \text { MW } & \text { Microwave } \\ \text { FCC } & \text { Federal Communication Commission } \\ \text { CP } & \text { Cold Plasma } \\ \text { ROS } & \text { Reactive Oxygen Species } \\ \text { DBD } & \text { Dielectric Barrier Discharge } \\ \text { US } & \text { Ultrasound } \\ \text { WHC } & \text { Water Holding Capacity } \\ \text { PEF } & \text { Pulsed Electric Field } \\ \text { UV } & \text { Ultraviolet } \\ \text { PL } & \text { Pulsed Light }\end{array}$

\section{References}

1. Troy, D.J.; Ojha, K.S.; Kerry, J.P.; Tiwari, B.K. Sustainable and consumer-friendly emerging technologies for application within the meat industry: An overview. Meat. Sci. 2016, 120, 2-9. [CrossRef] [PubMed]

2. FAO. Technical Guidance Principles of Risk-Based Meat Inspection and Their Application. 2019. Available online: http: //www.fao.org/3/ca5465en/CA5465EN.pdf (accessed on 10 November 2020).

3. Di Renzo, L.; Colica, C.; Carraro, A.; Goga, B.C.; Marsella, L.T.; Botta, R.; Colombo, M.L.; Gratteri, S.; Chang, T.F.M.; Droli, M.; et al. Food safety and nutritional quality for the prevention of non communicable diseases: The Nutrient, hazard Analysis and Critical Control Point process (NACCP). J. Transl. Med. 2015, 13, 1-13. [CrossRef] [PubMed]

4. CDC. Surveillance for Foodborne Disease Outbreaks, United States, 2017, Annual Report; Department of Health and Human Services, Centers for Disease Control and Prevention: Atlanta, GA, USA, 2017.

5. Omer, M.K.; Alvarez-Ordonez, A.; Prieto, M.; Skjerve, E.; Asehun, T.; Alvseike, O.A. A systematic review of bacterial foodborne outbreaks related to red meat and meat products. Foodborne Pathog. Dis. 2018, 15, 598-611. [CrossRef] [PubMed]

6. Zhao, Y.-M.; De Alba, M.; Sun, D.-W.; Tiwari, B. Principles and recent applications of novel non-thermal processing technologies for the fish industry-A review. Crit. Rev. Food Sci. Nutr. 2018, 59, 728-742. [CrossRef] [PubMed]

7. Petruzzi, L.; Corbo, M.R.; Sinigaglia, M.; Bevilacqua, A. Microbial spoilage of foods: Fundamentals. In The Microbiological Quality of Food; Elsevier: Amsterdam, The Netherlands, 2017; pp. 1-21. [CrossRef]

8. Fleet, G.H. Chapter 5-Yeast Spoilage of Foods and Beverages. In The Yeasts, 5th ed.; Kurtzman, C.P., Fell, J.W., Boekhout, T., Eds.; Elsevier: London, UK, 2011; pp. 53-63. [CrossRef]

9. Davidson, P.M.; Critzer, F.M. Interventions to Inhibit or Inactivate Bacterial Pathogens in Foods. In Microbial Food Safety; Springer: New York, NY, USA, 2011; pp. 189-202. [CrossRef]

10. Bennani, L.; Faid, M.; Bouseta, A. Experimental manufacturing of kaddid, a salted dried meat product: Control of the microorganisms. Eur. Food Res. Technol. 2000, 211, 153-157. [CrossRef]

11. Domowe, W. Safety Hurdles. 2010. Available online: http://www.wedlinydomowe.com/fermentedsausages/fermentedsausages-safety-hurdles.htm. (accessed on 11 November 2020).

12. USDA. FSRE (Food Safety Regulatory Essentials) Shelf-Stable, Principles of Preservation of Shelf-Stable Dried Meat Products. 2005; pp. 156-170. Available online: http:/ / www.fsis.usda.gov/PDF/FSRE_SS_7Principles.pdf. (accessed on 11 November 2020).

13. Cerveny, J.; Meyer, J.D.; Hall, P.A. Microbiological spoilage of meat and poultry products. In Compendium of the Microbiological Spoilage of Foods and Beverages; Springer: New York, NY, USA, 2009; pp. 69-86. [CrossRef]

14. Odeyemi, O.A.; Alegbeleye, O.O.; Strateva, M.; Stratev, D. Understanding spoilage microbial community and spoilage mechanisms in foods of animal origin. Compr. Rev. Food Sci. Food Saf. 2020, 19, 311-331. [CrossRef]

15. Mutwakil; Dave, D.; Ghaly, A.E. Meat Spoilage Mechanisms and Preservation Techniques: A Critical Review. Am. J. Agric. Biol. Sci. 2011, 6, 486-510. [CrossRef]

16. Luong, N.-D.M.; Coroller, L.; Zagorec, M.; Membré, J.-M.; Guillou, S. Spoilage of Chilled Fresh Meat Products during Storage: A Quantitative Analysis of Literature Data. Microorganisms 2020, 8, 1198. [CrossRef]

17. Ripolles-Avila, C.; García-Hernández, N.; Cervantes-Huamán, B.H.; Mazaheri, T.; Rodríguez-Jerez, J.J. Quantitative and Compositional Study of Monospecies Biofilms of Spoilage Microorganisms in the Meat Industry and Their Interaction in the Development of Multispecies Biofilms. Microorganisms 2019, 7, 655. [CrossRef] [PubMed]

18. Liu, F.; Guo, Y.-Z.; Li, Y.-F. Interactions of microorganisms during natural spoilage of pork at $5{ }^{\circ} \mathrm{C}$. J. Food Eng. 2006, 72, $24-29$. [CrossRef]

19. Leistner, L. Basic aspects of food preservation by hurdle technology. Int. J. Food Microbiol. 2000, 55, 181-186. [CrossRef] 
20. Sohaib, M.; Anjum, F.M.; Arshad, M.S.; Rahman, U.U. Postharvest intervention technologies for safety enhancement of meat and meat based products; a critical review. J. Food Sci. Technol. 2015, 53, 19-30. [CrossRef] [PubMed]

21. Sofos, J.N. Meat and Meat Products. In Food Safety Management; Academic Press: Cambridge, MA, USA, $2014 ;$ pp. 119-162. [CrossRef]

22. Sofos, J.N. Challenges to meat safety in the 21st century. Meat Sci. 2008, 78, 3-13. [CrossRef]

23. Cavus, S.; Tornuk, F.; Sarioglu, K.; Yetim, H. Determination of mold contamination and aflatoxin levels of the meat products/ingredients collected from Turkey market. J. Food Saf. 2018, 38, e12494. [CrossRef]

24. Shirai, H.; Datta, A.K.; Oshita, S. Penetration of aerobic bacteria into meat: A mechanistic understanding. J. Food Eng. 2017, 196, 193-207. [CrossRef]

25. Madoroba, E.; Magwedere, K.; Chaora, N.; Matle, I.; Muchadeyi, F.; Mathole, M.; Pierneef, R. Microbial Communities of Meat and Meat Products: An Exploratory Analysis of the Product Quality and Safety at Selected Enterprises in South Africa. Microorganisms 2021, 9, 507. [CrossRef]

26. Ahmed, A.M.; Shimamoto, T. Isolation and molecular characterization of Salmonella enterica, Escherichia coli O157:H7 and Shigella spp. from meat and dairy products in Egypt. Int. J. Food Microbiol. 2014, 168-169, 57-62. [CrossRef] [PubMed]

27. Sallam, K.I.; Abd-ElGhany, S.M.; Elhadidy, M.; Tamura, T. Molecular Characterization and Antimicrobial Resistance Profile of Methicillin-Resistant Staphylococcus aureus in Retail Chicken. J. Food Prot. 2015, 78, 1879-1884. [CrossRef]

28. Wu, S.; Huang, J.; Wu, Q.; Zhang, J.; Zhang, F.; Yang, X.; Wu, H.; Zeng, H.; Chen, M.; Ding, Y.; et al. Staphylococcus aureus Isolated From Retail Meat and Meat Products in China: Incidence, Antibiotic Resistance and Genetic Diversity. Front. Microbiol. 2018, 9, 2767. [CrossRef]

29. Li, M.; Huang, L.; Zhu, Y.; Wei, Q. Growth of Clostridium perfringens in roasted chicken and braised beef during cooling-One-step dynamic analysis and modeling. Food Control. 2019, 106, 106739. [CrossRef]

30. Shaltout, F.A.; Zakaria, I.M.; Nabil, M.E. Detection and typing of Clostridium perfringens in some retail chicken meat products. Benha Veter-Med. J. 2017, 33, 283-291. [CrossRef]

31. Pfrunder, S.; Grossmann, J.; Hunziker, P.; Brunisholz, R.; Gekenidis, M.-T.; Drissner, D. Bacillus cereus Group-Type Strain-Specific Diagnostic Peptides. J. Proteome Res. 2016, 15, 3098-3107. [CrossRef] [PubMed]

32. Kong, L.; Yu, S.; Yuan, X.; Li, C.; Yu, P.; Wang, J.; Guo, H.; Wu, S.; Ye, Q.; Lei, T.; et al. An Investigation on the Occurrence and Molecular Characterization of Bacillus cereus in Meat and Meat Products in China. Foodborne Pathog. Dis. 2021, 18, 306-314. [CrossRef] [PubMed]

33. Rahman, U.U.; Sahar, A.; Ishaq, A.; Aadil, R.M.; Zahoor, T.; Ahmad, M.H. Advanced meat preservation methods: A mini review. J. Food Saf. 2018, 38, e12467. [CrossRef]

34. Xiong, Y.L. The Storage and Preservation of Meat. In Lawrie's Meat Science; Woodhead publishing: Sawston, UK, 2017; pp. 205-230. [CrossRef]

35. Kaur, N.; Singh, A.K. Ohmic Heating: Concept and Applications-A Review. Crit. Rev. Food Sci. Nutr. 2015, 56, 2338-2351. [CrossRef] [PubMed]

36. Indiarto, R.; Rezaharsamto, B. A review on ohmic heating and its use in food. Int. J. Sci. Technol. Res. 2020, 9, 485-490.

37. Goullieux, A.; Pain, J.-P.; Goullieux, A.; Pain, J.-P. Ohmic Heating. In Emerging Technologies for Food Processing; Academic Press: Cambridge, MA, USA, 2014; pp. 399-426. [CrossRef]

38. Gavahian, M.; Tiwari, B.K.; Chu, Y.-H.; Ting, Y.-W.; Farahnaky, A. Food texture as affected by ohmic heating: Mechanisms involved, recent findings, benefits, and limitations. Trends Food Sci. Technol. 2019, 86, 328-339. [CrossRef]

39. Llave, Y.; Udo, T.; Fukuoka, M.; Sakai, N. Ohmic heating of beef at $20 \mathrm{kHz}$ and analysis of electrical conductivity at low and high frequencies. J. Food Eng. 2018, 228, 91-101. [CrossRef]

40. Engchuan, W.; Jittanit, W.; Garnjanagoonchorn, W. The ohmic heating of meat ball: Modeling and quality determination. Innov. Food Sci. Emerg. Technol. 2014, 23, 121-130. [CrossRef]

41. Chen, J.H.; Ren, Y.; Seow, J.; Liu, T.; Bang, W.S.; Yuk, H.G. Intervention Technologies for Ensuring Microbiological Safety of Meat: Current and Future Trends. Compr. Rev. Food Sci. Food Saf. 2012, 11, 119-132. [CrossRef]

42. Liu, W.; Lanier, T.C. Rapid (microwave) heating rate effects on texture, fat/water holding, and microstructure of cooked comminuted meat batters. Food Res. Int. 2016, 81, 108-113. [CrossRef]

43. Di Rosa, A.R.; Bressan, F.; Leone, F.; Falqui, L.; Chiofalo, V. Radio frequency heating on food of animal origin: A review. Eur. Food Res. Technol. 2019, 245, 1787-1797. [CrossRef]

44. Jiao, Y.; Tang, J.; Wang, Y.; Koral, T.L. Radio-Frequency Applications for Food Processing and Safety. Annu. Rev. Food Sci. Technol. 2018, 9, 105-127. [CrossRef] [PubMed]

45. Misra, N.N.; Yadav, B.; Roopesh, M.S.; Jo, C. Cold Plasma for Effective Fungal and Mycotoxin Control in Foods: Mechanisms, Inactivation Effects, and Applications. Compr. Rev. Food Sci. Food Saf. 2019, 18, 106-120. [CrossRef] [PubMed]

46. Whitehead, J.C. The Chemistry of Cold Plasma. In Cold Plasma in Food and Agriculture; Academic Press: Cambridge, MA, USA, 2016; pp. 53-81. [CrossRef]

47. Varilla, C.; Marcone, M.; Annor, G.A. Potential of Cold Plasma Technology in Ensuring the Safety of Foods and Agricultural Produce: A Review. Foods 2020, 9, 1435. [CrossRef] [PubMed]

48. Misra, N.; Jo, C. Applications of cold plasma technology for microbiological safety in meat industry. Trends Food Sci. Technol. 2017, 64, 74-86. [CrossRef] 
49. Lee, H.J.; Jung, H.; Choe, W.; Ham, J.S.; Lee, J.H.; Jo, C. Inactivation of Listeria monocytogenes on agar and processed meat surface by atmospheric pressure plasma jets. Food Microbiol. 2011, 28, 1468-1471. [CrossRef] [PubMed]

50. Jayasena, D.D.; Kim, H.J.; Yong, H.I.; Park, S.; Kim, K.; Choe, W.; Jo, C. Flexible thin-layer dielectric barrier discharge plasma treatment of pork butt and beef loin: Effects on pathogen inactivation and meat-quality attributes. Food Microbiol. 2015, 46, 51-57. [CrossRef]

51. Lee, H.; Yong, H.I.; Kim, H.-J.; Choe, W.; Yoo, S.J.; Jang, E.J.; Jo, C. Evaluation of the microbiological safety, quality changes, and genotoxicity of chicken breast treated with flexible thin-layer dielectric barrier discharge plasma. Food Sci. Biotechnol. 2016, 25, 1189-1195. [CrossRef]

52. Rossow, M.; Ludewig, M.; Braun, P.G. Effect of cold atmospheric pressure plasma treatment on inactivation of Campylobacter jejuni on chicken skin and breast fillet. LWT 2018, 91, 265-270. [CrossRef]

53. Chaplot, S.; Yadav, B.; Jeon, B.; Roopesh, M.S. Atmospheric Cold Plasma and Peracetic Acid-Based Hurdle Intervention To Reduce Salmonella on Raw Poultry Meat. J. Food Prot. 2019, 82, 878-888. [CrossRef] [PubMed]

54. Roh, S.H.; Oh, Y.J.; Lee, S.Y.; Kang, J.H.; Min, S.C. Inactivation of Escherichia coli O157:H7, Salmonella, Listeria monocytogenes, and Tulane virus in processed chicken breast via atmospheric in-package cold plasma treatment. LWT 2020, 127, 109429. [CrossRef]

55. Zhuang, H.; Rothrock, M.J., Jr.; Hiett, K.L.; Lawrence, K.C.; Gamble, G.R.; Bowker, B.C.; Keener, K.M. In-package air cold plasma treatment of chicken breast meat: Treatment time effect. J. Food Qual. 2019, 28, 801-807. [CrossRef]

56. Aaslyng, M.D.; Meinert, L. Meat flavour in pork and beef-From animal to meal. Meat Sci. 2017, 132, 112-117. [CrossRef] [PubMed]

57. Al-Hilphy, A.R.S.; Verma, D.K.; Kareem, A. Principles of Ultrasonic Technology for Treatment of Milk and Milk Products. In Food Process Engineering; Apple Academic Press: Palm Bay, FL, USA, 2016; pp. 211-236.

58. Al-Hilphy, A.R.; Al-Temimi, A.B.; Al Rubaiy, H.H.M.; Anand, U.; Delgado-Pando, G.; Lakhssassi, N. Ultrasound applications in poultry meat processing: A systematic review. J. Food Sci. 2020, 85, 1386-1396. [CrossRef] [PubMed]

59. Alarcon-Rojo, A.D.; Carrillo-Lopez, L.M.; Reyes-Villagrana, R.; Huerta-Jiménez, M.; Garcia-Galicia, I.A. Ultrasound and meat quality: A review. Ultrason. Sonochem. 2019, 55, 369-382. [CrossRef] [PubMed]

60. Alarcon-Rojo, A.; Janacua, H.; Rodriguez, J.; Paniwnyk, L.; Mason, T. Power ultrasound in meat processing. Meat Sci. 2015, 107, 86-93. [CrossRef] [PubMed]

61. McDonnell, C.; Lyng, J.; Allen, P. The use of power ultrasound for accelerating the curing of pork. Meat Sci. 2014, 98, 142-149. [CrossRef]

62. Gómez-Salazar, J.A.; Ochoa-Montes, D.A.; Ceron-Garcia, A.; Ozuna, C.; Sosa-Morales, M.E. Effect of Acid Marination Assisted by Power Ultrasound on the Quality of Rabbit Meat. J. Food Qual. 2018, 2018, 5754930. [CrossRef]

63. Piñon, M.; Alarcon-Rojo, A.; Renteria, A.; Carrillo-López, L.M. Microbiological properties of poultry breast meat treated with high-intensity ultrasound. Ultrasonics 2020, 102, 105680. [CrossRef] [PubMed]

64. Mok, J.H.; Her, J.-Y.; Kang, T.; Hoptowit, R.; Jun, S. Effects of pulsed electric field (PEF) and oscillating magnetic field (OMF) combination technology on the extension of supercooling for chicken breasts. J. Food Eng. 2017, 196, 27-35. [CrossRef]

65. Boateng, E.F.; Nasiru, M.M. Applications of Ultrasound in Meat Processing Technology: A Review. Food Sci. Technol. 2019, 7, 11-15. [CrossRef]

66. Režek, I.; Herceg, Z.; Grbavac, J. Possibilities of applying high power ultrasound in meat industry. Comput. Sci. 2014, 16, 356-361.

67. Kang, D.; Zhang, W.; Lorenzo, J.M.; Chen, X. Structural and functional modification of food proteins by high power ultrasound and its application in meat processing. Crit. Rev. Food Sci. Nutr. 2020, 61, 1914-1933. [CrossRef] [PubMed]

68. Gómez, B.; Munekata, P.E.S.; Gavahian, M.; Barba, F.J.; Martí-Quijal, F.J.; Bolumar, T.; Campagnol, P.C.B.; Tomašević, I.; Lorenzo, J.M. Application of pulsed electric fields in meat and fish processing industries: An overview. Food Res. Int. 2019, 123, 95-105. [CrossRef] [PubMed]

69. Gavahian, M.; Chu, Y.-H.; Sastry, S. Extraction from Food and Natural Products by Moderate Electric Field: Mechanisms, Benefits, and Potential Industrial Applications. Compr. Rev. Food Sci. Food Saf. 2018, 17, 1040-1052. [CrossRef] [PubMed]

70. Puértolas, E.; Koubaa, M.; Barba, F.J. An overview of the impact of electrotechnologies for the recovery of oil and high-value compounds from vegetable oil industry: Energy and economic cost implications. Food Res. Int. 2016, 80, 19-26. [CrossRef]

71. Barba, F.J.; Ahrné, L.; Xanthakis, E.; Landerslev, M.G.; Orlien, V. Innovative Technologies for Food Preservation. In Innovative Technologies for Food Preservation: Inactivation of Spoilage and Pathogenic Microorganisms; Academic Press: Cambridge, MA, USA, 2018; pp. 25-51. [CrossRef]

72. Puértolas, E.; Barba, F.J. Electrotechnologies applied to valorization of by-products from food industry: Main findings, energy and economic cost of their industrialization. Food Bioprod. Process. 2016, 100, 172-184. [CrossRef]

73. Khan, A.A.; Randhawa, M.A.; Carne, A.; Ahmed, I.A.M.; Barr, D.; Reid, M.; Bekhit, A.E.-D. Effect of low and high pulsed electric field on the quality and nutritional minerals in cold boned beef M. longissimus et lumborum. Innov. Food Sci. Emerg. Technol. 2017, 41, 135-143. [CrossRef]

74. Ma, Q.; Hamid, N.; Oey, I.; Kantono, K.; Faridnia, F.; Yoo, M.; Farouk, M. Effect of chilled and freezing pre-treatments prior to pulsed electric field processing on volatile profile and sensory attributes of cooked lamb meats. Innov. Food Sci. Emerg. Technol. 2016, 37, 359-374. [CrossRef]

75. Bhat, Z.F.; Morton, J.D.; Mason, S.L.; Bekhit, A.E.-D.A. Current and future prospects for the use of pulsed electric field in the meat industry. Crit. Rev. Food Sci. Nutr. 2018, 59, 1660-1674. [CrossRef] [PubMed] 
76. Bekhit, A.E.-D.A.; Suwandy, V.; Carne, A.; van de Ven, R.; Hopkins, D. Effect of repeated pulsed electric field treatment on the quality of hot-boned beef loins and topsides. Meat Sci. 2016, 111, 139-146. [CrossRef]

77. Suwandy, V.; Carne, A.; van de Ven, R.; Bekhit, A.E.-D.; Hopkins, D. Effect of pulsed electric field on the proteolysis of cold boned beef M. Longissimus lumborum and M. Semimembranosus. Meat Sci. 2015, 100, 222-226. [CrossRef] [PubMed]

78. Indiarto, R.; Pratama, A.W.; Sari, T.I.; Theodora, H.C. Food Irradiation Technology: A Review of The Uses and Their Capabilities. Int. J. Eng. Trends Technol. 2020, 68, 91-98. [CrossRef]

79. Indiarto, R.; Qonit, M.A.H. A review of irradiation technologies on food and agricultural products. Int. J. Sci. Technol. Res. 2020, 9 , 4411-4414.

80. Maherani, B.; Hossain, F.; Criado, P.; Ben-Fadhel, Y.; Salmieri, S.; Lacroix, M. World Market Development and Consumer Acceptance of Irradiation Technology. Foods 2016, 5, 79. [CrossRef] [PubMed]

81. Jayathilakan, K.; Sultana, K.; Pandey, M.C. Radiation Processing: An Emerging Preservation Technique for Meat and Meat Products. Def. Life Sci. J. 2017, 2, 133. [CrossRef]

82. Ravindran, R.; Jaiswal, A.K. Wholesomeness and safety aspects of irradiated foods. Food Chem. 2019, 285, 363-368. [CrossRef] [PubMed]

83. Ricciardi, E.F.; Lacivita, V.; Conte, A.; Chiaravalle, E.; Zambrini, A.V.; Del Nobile, M.A. X-ray irradiation as a valid technique to prolong food shelf life: The case of ricotta cheese. Int. Dairy J. 2019, 99, 104547. [CrossRef]

84. Roberts, P.B. Food irradiation: Standards, regulations and world-wide trade. Radiat. Phys. Chem. 2016, 129, 30-34. [CrossRef]

85. Vasuja, S.; Kumar, V. Ultraviolet Irradiation and its applications in Food Processing Industries: A Review. Int. J. Trend Res. Dev. 2018, 5, 343-346.

86. Singh, P.K.; Verma, A.K.; Ranjan, R.; Singh, T.P.; Kumar, D.; Kumar, P. Non thermal preservation of meat by irradiation: A review. J. Food Res. Technol. 2015, 3, 7-13.

87. Park, S.Y.; Ha, S.-D. Ultraviolet-C Radiation on the Fresh Chicken Breast: Inactivation of Major Foodborne Viruses and Changes in Physicochemical and Sensory Qualities of Product. Food Bioprocess. Technol. 2014, 8, 895-906. [CrossRef]

88. Bottino, F.D.O.; Rodrigues, B.L.; de Nunes Ribeiro, J.D.; Lázaro, C.A.D.L.T.; Conte-Junior, C.A. Influence of UV-C Radiation on Shelf Life of Vacuum Package Tambacu (Colossoma macropomum $\times$ Piaractus mesopotamicus) Fillets. J. Food Process. Preserv. 2017, 41, e13003. [CrossRef]

89. Silva, H.; Costa, M.; Frasao, B.; Mesquita, E.; Mello, S.C.R.P.; Conte-Junior, C.; Franco, R.M.; Miranda, Z. Efficacy of Ultraviolet-C Light to Eliminate S taphylococcus Aureus on Precooked Shredded Bullfrog Back Meat. J. Food Saf. 2015, 35, 318-323. [CrossRef]

90. Vasilev, D.; Stajkovic, S.; Karabasil, N.; Dimitrijevic, M.; Teodorovic, V. Perspectives in meat processing. IOP Conf. Series: Earth Environ. Sci. 2019, 333, 012024. [CrossRef]

91. Mahendran, R.; Ramanan, K.R.; Barba, F.J.; Lorenzo, J.M.; Fernández, O.L.; Munekata, P.E.S.; Roohinejad, S.; Sant'Ana, A.S.; Tiwari, B.K. Recent advances in the application of pulsed light processing for improving food safety and increasing shelf life. Trends Food Sci. Technol. 2019, 88, 67-79. [CrossRef]

92. Tomasevic, I.; Djekic, I.; Novaković, S.; Barba, F.; Lorenzo, J.M. The feasibility of pulsed light processing in the meat industry. IOP Conf. Series: Earth Environ. Sci. 2019, 333, 012034. [CrossRef]

93. Rajkovic, A.; Tomasevic, I.; De Meulenaer, B.; Devlieghere, F. The effect of pulsed UV light on Escherichia coli O157:H7, Listeria monocytogenes, Salmonella Typhimurium, Staphylococcus aureus and staphylococcal enterotoxin A on sliced fermented salami and its chemical quality. Food Control. 2017, 73, 829-837. [CrossRef]

94. Koch, F.; Wiacek, C.; Braun, P.G. Pulsed light treatment for the reduction of Salmonella Typhimurium and Yersinia enterocolitica on pork skin and pork loin. Int. J. Food Microbiol. 2018, 292, 64-71. [CrossRef] [PubMed]

95. Bolumar, T.; Orlien, V.; Sikes, A.; Aganovic, K.; Bak, K.H.; Guyon, C.; Stübler, A.; de Lamballerie, M.; Hertel, C.; Brüggemann, D.A. High-pressure processing of meat: Molecular impacts and industrial applications. Compr. Rev. Food Sci. Food Saf. 2020, 20, 332-368. [CrossRef] [PubMed]

96. Jung, S.; Tonello-Samson, C. Chapter 7. High Hydrostatic Pressure Food Processing: Potential and Limitations. In Alternatives to Conventional Food Processing; Royal Society of Chemistry: London, UK, 2018; pp. 251-315. [CrossRef]

97. Sukmanov, V.; Hanjun, M.; Li, Y.-P. Effect of high pressure processing on meat and meat products. A review. Ukr. Food J. 2019, 8, 448-469. [CrossRef]

98. Ma, Y.; Yuan, Y.; Bi, X.; Zhang, L.; Xing, Y.; Che, Z. Tenderization of Yak Meat by the Combination of Papain and High-Pressure Processing Treatments. Food Bioprocess. Technol. 2019, 12, 681-693. [CrossRef]

99. Wgiorgis, G.A.; Yildiz, F. Review on high-pressure processing of foods. Cogent Food Agric. 2019, 5, 1568725. [CrossRef]

100. Hygreeva, D.; Pandey, M. Novel approaches in improving the quality and safety aspects of processed meat products through high pressure processing technology-A review. Trends Food Sci. Technol. 2016, 54, 175-185. [CrossRef]

101. Horita, C.N.; Baptista, R.C.; Caturla, M.Y.; Lorenzo, J.M.; Barba, F.J.; Sant'Ana, A.S. Combining reformulation, active packaging and non-thermal post-packaging decontamination technologies to increase the microbiological quality and safety of cooked ready-to-eat meat products. Trends Food Sci. Technol. 2018, 72, 45-61. [CrossRef] 